\title{
EVALUATING THE IMPLICATIONS OF CORRUPTION PRACTISES ON FIRM INNOVATIVENESS CAPACITIES: EVIDENCE A 2019 SURVEY IN ALBANIA
}

\author{
Brunilda KOSTA \\ Management Department, Faculty of Economy \\ University of Tirana
}

Received: 30. March 2020, 2020; Reviewed 16. May 2020, Accepted 07. June 2020

\begin{abstract}
This paper evaluates empirically the relationship between corruption and innovation, in the context of a developing economy. There are two different theses that argue on the corruption effects on firms' innovativeness capacities. "Sanding the wheels" thesis supports the harmful impact corruption has on innovation while "greasing the wheels" thesis supports the positive impact corruption has on innovation. This papers seeks to test the "grease the wheels" thesis. To do this, data is reported from the World Bank Enterprise Survey (WBES) on 377 enterprises in Albania, collected in 2019. After controlling for other determinants of innovation, the finding is that corruptions harms firms' innovativeness capacities. This finding supports the "sand the wheel" thesis. Theoretical and policy implications are then discussed.
\end{abstract}

Key words: corruption, product innovation, process innovation, Albania.

JEL Classification: O30, D73, O17

\section{Introduction}

There is a long-standing acceptance on the profound role innovation plays into spurring economic growth (Rosenberg, 2004). Moreover, innovation is conceptually and empirically proved to enhance firm performance and help them gain a competitive advantage (Schumpeter, 1934; Love and Roper, 2015). There are various definitions on innovation. The most cited one in the literature, is that provided by Schumpeter (1911). Known as the founder of the economic theory of innovations, Schumpeter defines innovation as the provision of new products of services, new processes, raw materials, new markets and new organization.

A growing stream of research are putting innovation on a spotlight. Most of studies shed light on the drivers of innovation (Furman et al., 2002) while not too much attention has been provided to the role of institutions on hampering/fostering innovation (Hong et al., 2012). According to the institutional theory (North, 1990), institutions shapes the economic agents' attitude and determine level of innovation 
(Barasa et al., 2017). Furthermore, institutions have an underlying impact on the competiveness of firms (Kumar et al., 2013).

One of the most important features of institutional weaknesses, remains corruption which has both implications on national basis (national economy) (Mauro, 1995) and firm level (Rodriguez et al., 2005). Among plethora of definitions given to corruption, Mauro (1995) defines it as the misuse of public office for private gains. On the same line, goes the definition of Transparency International which defines it as the "abuse of entrusted power for private gain". There is a twofold dimensional implications scholars lay out about corruption. The first view is that of "sanding the wheels". As per this view, corruption hampers firm's innovativeness capabilities due to the increase of transaction costs, uncertainty (Fisman and Svensson, 2007), and barriers to investment (Hakkala et al., 2008). Contrary to this, the second view is that of "greasing the wheels". According this view, corruption avoids unnecessary red tapes of official procedures, thus increasing efficiency and consequently busting innovation (Leff, 1964).

Drawing on the institutional theory, this paper endeavors to evaluate empirically "greasing the wheel" thesis, utilizing the most recent data of World Bank Enterprise Survey (2019). This thesis is tested using data on 377 firms operating in Albania. To the best of my knowledge, investigating this relationship has not been developed so far in Albania.

Albania is a developing country, manifesting a high level of corruption. According to the Corruption Perception Index (CPI) 2018, Albania is placed at 99 among the 180 countries. Albania scored 36 out of 100 points, experiencing a reduction of two points from the 2017 rating. Albania has made progress in tackling corruption. However, it still remains prevalent and a serios problem of the national economy. In addition of statistics provided by TI on national basis, corruption continues to be a key obstacle of doing business on firm level, too. This is confirmed by the latest World Bank Enterprise Survey (2019).

To build this study hypotheses, this paper relies on the arguments provided by the institutional theory which aims to explain the adoption of formal organizational structures, in terms of rules, beliefs, and norms of external environment (North, 1990). This theory has a twofold support in this paper. First, it gives importance to the context firms operate and second, it gives importance to strategic decisions undertaken by firms, such as for example innovation (Martin et al. 2007). Institutional theory has been suggested as a third leg in strategic management (Peng et al., 2009). In addition, corrupting has been referred as a reflection of the weak institutional environment (Vaal and Ebben, 2011).

Developing economies are characterized by a weak role of states (Rice and Patric, 2008). As new institutional economics perspective explains, weak institutions hamper the private sector returns to investment through various mechanisms: contractual incompleteness, hold-up problems, corruption, lack of property rights, and poor contract enforcement (North, 1990; Acemoglu et al., (2001). Under such circumstances, firms will try to overcome these burdens using corruption.

This paper endeavors to empirically test the "greasing the wheels" thesis. All conceptual arguments that support this perspective, fall under two different lenses. First, corruption helps private sector to reduce uncertainty and risks which are yielded from political factors. Put in simple words, private sector willing to innovate might be facing several burdens and risks which intervene their business activities. Under these conditions, firms choose to give bribes thus to easily overcome burdens and mitigate the associated risks (Leff, 1964). Second, corruption helps private sector to reduce red tapes of procedural processes and to increase efficiency. Innovation 
is a process which requires time. The last stage of innovation process, requires firms to protect their outcome. This requires firm to take multiple actions such as approvals, permits, licenses etc. so to close all the cyclic process and provide the final product to its customers. This is the case when firms prefer to avoid wasting time and get things done fast through corruption.

Besides conceptual arguments, the "greasing the wheel" thesis has been investigated by various empirical studies. Xia et al., (2018) in their survey developed in the context of China, found a significant positive impact of corruption into innovation. Similarly, the same finding is confirmed in another study developed in Vietnam, thus supporting the "greasing the wheel" thesis (Nguyen et al., 2016). A recent study uncovered that political corruption benefits firms in most of their innovative activities (Riaz and Cantner, 2020). Other bulk of empirical studies confirm the greasing impact of corruption on innovation (Goedhuys et al., 2016; Imran et al., 2020). A wide survey developed in 30 transition economies with 7,000 firms, revealed the positive effect corruption has on innovation (Krammer, 2013).

are build:

Based on the conceptual and empirical arguments, the following hypotheses

Hypothesis 1: Corruption fosters firm's capacities to innovate its products.

Hypothesis 2: Corruption fosters firm's capacities to innovate its processes.

\section{Material and Methods}

\section{Data}

To empirically test the study hypotheses, the latest WBES survey conducted in 2019 in Albania is reported. The sample consist of 377 firms, with five or more employees. Data were collected using a stratified random sample. Stratification was designed using three criteria: size, sector and region. Firm size is measured considering the number of employees. Small firms are those with 5-19 employees, medium firms are those with 20-99 employees and large firms are those with more than 100 employees. Sector included only those firms operating in the manufacturing, services, transportation and construction sector. In terms of the third stratification criteria, the survey considered three main regions: Northern Albania, Central Albania and Southern Albania.

\section{Variables}

\section{Dependent variables}

In this study, dependent variable is innovation which is measured by product innovation and process innovation. This categorization has been built referring to the OECD Oslo Manual (2005). This manual lists down several types of innovation. We single out product and process innovation which are closely connected to technological developments. Product innovation is defined as the ability of firms to introduce new or significantly improved goods or services while process innovation refers to the ability of firms to introduce new or significantly improved production or delivery methods (OECD Oslo Manual, 2005). Product innovation is a dummy variable that takes value 1 if the establishment has introduced new or improved products or services over the span of last three years and takes value 0 if otherwise. Process 
innovation is a dummy variable that takes value 1 if the establishment has introduced new or improved processes over the last three years and takes value 0 if otherwise.

\section{Key independent variable}

Corruption is the key independent variable and referring to the World Bank Enterprise Survey instrument, we use the following question to measure it:

"It is said that establishments are sometimes required to make informal payments or gifts to public officials to "get things done" with regard to licenses, regulations, services and so forth. On average, what percentage of total annual sales, or estimated total annual value, do establishments like this one pay in informal payments or gifts to public officials for this purpose?"

We transformed this question into a dummy variable, recoded with 1 if the company asserted a specific average of total annual sales given as informal payment, and 0 it otherwise (asserting that they have not given any informal payments to get their business things done).

\section{Control variables}

Besides the key independent variable, this paper controls for other variables which are widely accepted to impact firms' innovativeness capacities. All these control variables, are measures as following:

Firm size: This is a continuous variable which is measured with number of employees. There is a wide body of empirical research that confirm size of the firm to be a determinant of innovation. Some suggest that larger firms are more inclined to innovate (Ettlie and Rubenstein, 1987) while some others suggest the opposite (Hansen, 1992).

Firm age: This is a continuous variable which measures the number of years the establishment has been operating in the market. Firm age is accepted to be an underlying characteristic which might help new firms entering in the market. Other studies confirm that more experienced firms might innovate thus to keep their market share and gain a competitive advantage (Schumpeter, 1934, 1943; Christensen, 1997).

Export orientation: This is a dichotomous variable which takes value 1 if at least 1 percent of firm's sales comes from export and 0 if otherwise. Various empirical studies have highlighted the positive relationship between export orientation and firm innovation (Kosta and Busho, 2019; Palangkaraya, 2012).

Female top manager: This is a dichotomous variable which takes value 1 if the top manager of the firm is female and 0 if otherwise. Some empirical studies suggest that firms governed by female managers, are less likely to innovate while some other found gender to have a moderation effect (Ruiz-Jiménez and Fuentes-Fuentes, 2015).

Research and Development: This is a dichotomous variable which takes value 1 if the establishment has invested in R\&D over the span of last three years, and 0 if otherwise. National level and firm level research studies confirm a significant positive relationship of R\&D on innovation (Pegkas et al., 2019).

Access to finance: This is a categorical variable measured through a four Liker scale where 4 means that is represent a very severe obstacle, 3 means it represent a major obstacle, 2 means it represents a moderate obstacle, 1 means it represents a minor obstacle while 0 means it is not an obstacle. This variable is recoded with 1 if it represents a very severe/major obstacle and 0 if otherwise. Access to finance is highlighted to be an important determinant of firm innovation. Among other determinants of 
innovation, the capacity to access finance represent an important factor of innovation success (D'Este et al., 2011).

Labor regulations: This is a categorical variable measured through a four Liker scale where 4 means that is represent a very severe obstacle, 3 means it represent a major obstacle, 2 means it represents a moderate obstacle, 1 means it represents a minor obstacle while 0 means it is not an obstacle. This variable is recoded with 1 if it represents a very severe/major obstacle and 0 if otherwise. Studies confirm that severe labour regulations, discourage firm to innovate (Aghion and Bergeaud, 2019).

Informal competition: This is a categorical variable measured through a four Liker scale where 4 means that is represent a very severe obstacle, 3 means it represent a major obstacle, 2 means it represents a moderate obstacle, 1 means it represents a minor obstacle while 0 means it is not an obstacle. This variable is recoded with 1 if it represents a very severe/major obstacle and 0 if otherwise. There is a wide acceptance of the negative representation of informal competition into innovation (Heredia et al., 2017).

\section{Modelling Framework}

In this study, the dependent variable is dichotomous. Thus, binary logistic regression model is employed to perform the analysis. The final model has the following pattern.

$$
\operatorname{Ln}\left(\frac{p_{i}}{1-p_{i}}\right)=\beta_{0}+\beta_{1} x_{i}+\ldots+\beta_{k} x_{k}
$$

Where $p_{i}$ the probability that a firm has innovated over the span of last three years, $1-p_{i}$ is the probability the firm has not innovated, $\beta_{0}$ is the constant of the equation and $\beta_{k}(k=1,2, \ldots k)$ are the coefficients of the independent variables.

The logistic probability function takes the following form:

$$
p=\left(e^{\beta 0+\beta 1 x 1+\ldots+\beta k x k}\right) /\left(1+e^{\beta 0+\beta 1 x 1+\ldots+\beta k x k}\right)
$$

where $p$ is the likelihood of firm to innovate.

Table 1: Summary statistics

\begin{tabular}{|l|c|c|c|c|c|}
\hline \multicolumn{5}{|c|}{ Descriptive Statistics } \\
\hline & $\mathrm{N}$ & $\begin{array}{c}\text { Mini- } \\
\text { mum }\end{array}$ & $\begin{array}{c}\text { Maxi- } \\
\text { mum }\end{array}$ & Mean & $\begin{array}{c}\text { Std. } \\
\text { Deviation }\end{array}$ \\
\hline Exporter & 245 & 0 & 1 & .34 & .474 \\
\hline Product innovation & 247 & 0 & 1 & .32 & .466 \\
\hline Process innovation & 245 & 0 & 1 & .23 & .423 \\
\hline Corruption & 243 & 0 & 1 & .33 & .471 \\
\hline Female top management & 247 & 0 & 1 & .17 & .373 \\
\hline Labor regulations & 247 & 0 & 1 & .03 & .177 \\
\hline Access to finance & 247 & 0 & 1 & .15 & .362 \\
\hline
\end{tabular}




\begin{tabular}{|l|c|c|c|c|c|}
\hline Informal competition as an obstacle & 240 & 0 & 1 & .33 & .472 \\
\hline Research and Development & 247 & 0 & 1 & .20 & .400 \\
\hline Firm age (log) & 246 & .30 & 1.46 & 1.0569 & .31031 \\
\hline Firm size (log) & 247 & .48 & 2.96 & 1.4554 & .59170 \\
\hline
\end{tabular}

Source: own processing

Table 2: Correlation matrix

\begin{tabular}{|l|c|c|c|c|c|c|c|c|c|c|c|}
\hline & 1 & 2 & 3 & 4 & 5 & 6 & 7 & 8 & 9 & 10 & 11 \\
\hline Exporter & 1 & & & & & & & & & & \\
\hline $\begin{array}{l}\text { Product } \\
\text { innovation }\end{array}$ &, 029 & 1 & & & & & & & & & \\
\hline $\begin{array}{l}\text { Process } \\
\text { innovation }\end{array}$ & $.236^{* *}$ & $.147^{*}$ & 1 & & & & & & & & \\
\hline Corruption &, 082 & $-.157^{*}$ & $.188^{* *}$ & 1 & & & & & & & \\
\hline $\begin{array}{l}\text { Female top } \\
\text { management }\end{array}$ & $.174^{* *}$ &,- 022 &,- 040 &,- 058 & 1 & & & & & & \\
\hline $\begin{array}{l}\text { Labor } \\
\text { regulations }\end{array}$ &, 063 &,- 026 &, 008 &, 036 &, 103 & 1 & & & & & \\
\hline $\begin{array}{l}\text { Access to } \\
\text { finance }\end{array}$ & $.194^{* *}$ &,- 048 & $.145^{*}$ & $.253^{* *}$ &, 051 &, 112 & 1 & & & & \\
\hline $\begin{array}{l}\text { Informal } \\
\text { competition } \\
\text { as an obstacle }\end{array}$ &, 046 &, 070 & $.177^{* *}$ & $.297^{* *}$ &,- 055 &, 088 & $.198^{* *}$ & 1 & & & \\
\hline $\begin{array}{l}\text { Research and } \\
\text { Development }\end{array}$ &, 038 &, 055 &,- 058 & $-.221^{* *}$ &,- 058 &,- 091 &,- 100 & $-.133^{*}$ & 1 & & \\
\hline Firm age (log) &, 107 &,- 015 &, 091 &, 124 &,- 074 &,- 066 &, 052 & $.189^{* *}$ &,- 015 & 1 & \\
\hline $\begin{array}{l}\text { Firm size } \\
\text { (log) }\end{array}$ & $.542^{* *}$ & $.139^{*}$ & $.301^{* *}$ &, 097 &, 095 &,- 017 &, 052 &, 088 &,- 036 & $.181^{* *}$ & 1 \\
\hline
\end{tabular}

Source: own processing

**. Correlation is significant at the 0.01 level (2-tailed).

*. Correlation is significant at the 0.05 level (2-tailed).

\section{Results and Debate}

As a general finding, our results indicate that 33 percent of respondents assert they have made informal payments to public officials, to get things done. This means that the phenomenon of corruption is widespread in Albania. When it comes to the determinants of innovation Model 1 reports the impact of corruption into product innovation while Model 2 reports the impact of corruption into process innovation.

Model 1 reveals that corruption harms innovation capacities of firms, expressed in product innovation. This reveals a significant negative relationship between corruption and product innovation. This rejects our hypothesis thus confirming the "sanding the wheels" approach. When controlling for other determinants of product innovation, results show that the bigger the firm, the high the likelihood to innovative. Informal competition seems to foster product innovation and this reveals a significant relationship. 
Model 2 which evaluates the impact of corruption into process innovation, uncovers no significant relationship between these variables. In terms of control variables, the finding related to firm's size, is persistent as in Model 1.

Table 3: Results of logistic regression

\begin{tabular}{|l|c|c|}
\hline & $\begin{array}{c}\text { Model 1: Product } \\
\text { innovation }\end{array}$ & $\begin{array}{c}\text { Model 2: Process } \\
\text { innovation }\end{array}$ \\
\cline { 2 - 3 } & Coef (S.E) & Coef (S.E) \\
\hline Exporter &,$- 161(, 382)$ &, $528(, 403)$ \\
\hline Corruption &,$- 977(, 360)^{* * *}$ &,$- 772(, 513)$ \\
\hline Female top management &,$- 308(, 416)$ &, $192(, 951)$ \\
\hline Labor regulations &,$- 009(, 910)$ &, $466(, 449)$ \\
\hline Access to finance &,$- 201(, 452)$ &, $525(, 360)$ \\
\hline $\begin{array}{l}\text { Informal competition as } \\
\text { an obstacle }\end{array}$ &, $546(, 332)^{*}$ &,$- 413(, 479)$ \\
\hline $\begin{array}{l}\text { Research and } \\
\text { Development }\end{array}$ &, $111(, 364)$ &, $215(, 608)$ \\
\hline Firm age (log) &,$- 290(, 488)$ &, $996(, 333)^{* * *}$ \\
\hline Firm size (log) &, $628(, 304)^{* *}$ & $-3,464(, 808)^{* * *}$ \\
\hline Constant & $-1,157(, 616)^{*}$ & 79,3 \\
\hline Pseudo R square & 6886 & 232 \\
\hline Correctly classified & 234 & \\
\hline Observations & & \\
\hline Source: & 68,8 & \\
\hline
\end{tabular}

Source: own processing

Standard errors in parentheses: ${ }^{* *} p<0,01,{ }^{* *} p<0,05,{ }^{*} p<0,1$.

\section{Conclusion}

Analyzing 2019 WBES data, results reveals that in Albania, one in thirteen private sector enterprises with five or more employees has provided informal payments to public officials thus to get their business things done. After controlling for other determinants of product innovation, results uncover a significant negative relationship between corruption and product innovation, thus confirming the perspective of "sanding the wheel". When it comes to the impact of corruption into process innovation, no significant relationship is tested.

This finding has important implications on theoretical basis. By showing the negative impact corruption has on innovation, it contributes to the advancement of the theory of the "sanding the wheels" thesis. This means that deficiencies of formal institutional environment reflected into the wide accepted phenomenon of corruption, lead to the reduction of firms' innovativeness capacities and loss of potential investment. In terms of policy implications, this finding calls the design of effective policies on combating corruption. Specifically, government should undertake policy measures 
to reduce rep tapes in the process of obtaining licenses or permits. In addition, a holistic approach should be pursed thus effectively tackling corruption.

In sum, this paper has revealed that corruption harms firms' innovativeness capacities, in the context of Albania. If this foster similar research in other contexts, especially in developing countries and evaluation of the "sanding the wheels" approach, then this paper has fulfilled one of its intention. If this paper stimulates the design of effective policies to combat corruption, then the paper has fulfilled its second intention.

\section{Bibliography}

1. Acemoglu, D., Johnson, S., Robinson, J., \& Thaicharoen, Y. (2003). Institutional causes, macroeconomic symptoms: volatility, crises and growth. Journal of monetary economics, 50(1), 49-123.

2. Aghion, P., Bergeaud, A., Lequien, M., \& Melitz, M. J. (2018). The impact of exports on innovation: Theory and evidence.

3. Barasa, L., Knoben, J., Vermeulen, P., Kimuyu, P., \& Kinyanjui, B. (2017). Institutions, resources and innovation in East Africa: A firm level approach. Research Policy, 46(1), 280-291.

4. Christensen, C. M. (1997). The Innovator's Dilemma. Harvard Business School Press. Boston, MA.

5. David, P. A. (2001). Path dependence, its critics and the quest for 'historical economics'. Evolution and path dependence in economic ideas: Past and present, 15,40 .

6. De Vaal, A., \& Ebben, W. (2011). Institutions and the relation between corruption and economic growth. Review of Development Economics, 15(1), 108-123.

7. Ettlie, J. E., \& Rubenstein, A. H. (1987). Firm size and product innovation. Journal of Product Innovation Management: An International Publication of the Product Development \& Management Association, 4(2), 89-108.

8. Fisman, R., \& Svensson, J. (2007). Are corruption and taxation really harmful to growth? Firm level evidence. Journal of development economics, 83(1), 63-75.

9. Furman, J. L., Porter, M. E., \& Stern, S. (2002). The determinants of national innovative capacity. Research policy, 31(6), 899-933.

10. Goedhuys, M. (2007). Learning, product innovation, and firm heterogeneity in developing countries; Evidence from Tanzania. Industrial and Corporate Change, 16(2), 269-292.

11. Hakkala, K. N., Norbäck, P. J., \& Svaleryd, H. (2008). Asymmetric effects of corruption on FDI: evidence from Swedish multinational firms. The Review of Economics and Statistics, 90(4), 627-642.

12. Hansen, J. A. (1992). Innovation, firm size, and firm age. Small Business Economics, $4(1), 37-44$.

13. Heredia, J., Flores, A., Geldes, C., \& Heredia, W. (2017). Effects of informal competition on innovation performance: the case of pacific alliance. Journal of technology management \& innovation, 12(4), 22-28.

14. Heredia, J., Flores, A., Geldes, C., \& Heredia, W. (2017). Effects of informal competition on innovation performance: the case of pacific alliance. Journal of technology management \& innovation, 12(4), 22-28.

15. Hong, S., Oxley, L., \& McCann, P. (2012). A survey of the innovation surveys. Journal of economic surveys, 26(3), 420-444. 
16. Imran, S. M., Rehman, H. U., \& Khan, R. E. A. (2020). Effect of corruption on firm level innovation: Evidence from Pakistan. Economics and Business Letters, 9(1), 41-47.

17. Kosta, B., \& Busho, N. (2019). The Effects of Process Innovation's Dimension into Product Innovation-A Comparative Firm Level Analysis from EU and Non-EU Countries. EMAN 2019-Economics \& Management: How to Cope with Disrupted Times, 441.

18. Kumar, V., Mudambi, R., \& Gray, S. (2013). Internationalization, innovation and institutions: The 3 I's underpinning the competitiveness of emerging market firms. Journal of International Management, 19(3), 203-206.

19. Krammer, S. M. S. (2013). Greasing the wheels of change: the impact of corruption on firms innovation in transition economies. In 35th DRUID Celebration Conference (pp. 17-19).

20. Leff, N. H. (1964). Economic development through bureaucratic corruption. American behavioral scientist, 8(3), 8-14.

21. Love, J. H., \& Roper, S. (2015). SME innovation, exporting and growth: A review of existing evidence. International small business journal, 33(1), 28-48.

22. Martin, K. D., Cullen, J. B., Johnson, J. L., \& Parboteeah, K. P. (2007). Deciding to bribe: A cross-level analysis of firm and home country influences on bribery activity. Academy of Management Journal, 50(6), 1401-1422.

23. Mauro, M. P. (1996). The Effects of Corruptionon Growth, Investment, and Government Expenditure (No. 96-98). International Monetary Fund.

24. Nguyen, N. A., Doan, Q. H., Nguyen, N. M., \& Tran-Nam, B. (2016). The impact of petty corruption on firm innovation in Vietnam. Crime, Law and Social Change, 65(4-5), 377-394.

25. North, D. C. (1991). Institutions. Journal of economic perspectives, 5(1), 97-112.

26. Palangkaraya, A. (2012). The link between innovation and export: Evidence from Australia's small and medium enterprises. ERIA Discussion Paper, 8.

27. Pegkas, P., Staikouras, C., \& Tsamadias, C. (2019). Does research and development expenditure impact innovation? Evidence from the European Union countries. Journal of Policy Modeling, 41(5), 1005-1025.

28. Riaz, M. F., \& Cantner, U. (2019). Revisiting the relationship between corruption and innovation in developing and emerging economies. Crime, Law and Social Change, 1-22.

29. Rice, S. E., \& Patrick, S. (2008). Index of state weakness in the developing world (p. 14). Washington, DC: Brookings Institution.

30. Rodriguez, P., Uhlenbruck, K., \& Eden, L. (2005). Government corruption and the entry strategies of multinationals. Academy of management review, 30(2), 383396.

31. Rosenberg, N. (2004). Innovation and economic growth. Professor of Economics (Emeritus).

32. Ruiz-Jiménez, J. M., \& del Mar Fuentes-Fuentes, M. (2016). Management capabilities, innovation, and gender diversity in the top management team: An empirical analysis in technology-based SMEs. BRQ Business Research Quarterly, 19(2), 107-121.

33. Schumpeter, J. (1912). The Theory of Economic Development, published in 1934. Harvard Economic Studies, Cambridge.

34. Oecd, E. (2005). Oslo manual: Guidelines for collecting and interpreting innovation data. Paris 2005, Sp, 46.

35. Transparency International (2019). How do you define corruption? Retrieved from https://www. transparency.org/what-is-corruption. 
36. Xia, H., Tan, Q., \& Bai, J. (2018). Corruption and Technological Innovation in Private Small-Medium Scale Companies: Does Female Top Management Play a Role?. Sustainability, 10(7), 2252.

37. Zhang, J., \& Zhu, M. (2016). Market orientation, product innovation and export performance: evidence from Chinese manufacturers. Journal of Strategic Marketing, 24(5), 377-397.

\section{Correspondence address:}

Brunilda Kosta, Assistant Professor, Management Department, Faculty of Economy, University of Tirana, “Arben Broci” street, 1000, Tirana, Albania, brunildakosta@feut.edu. al 